\title{
Peritonite por Salmonella em paciente em diálise peritoneal automática
}

\author{
Salmonella peritonitis in a patient on automated peritoneal dialysis
}

\section{Authors}

Moisés Carminatti ${ }^{1}$

Thiago Lacet $^{1}$

Dominique Fonseca

Rodrigues $^{2}$

Maria de Lourdes

Junqueira ${ }^{3}$

Fernando César

Rodrigues $^{3}$

Marcus Gomes

Bastos $^{4}$

Natália Maria da Silva

Fernandes $^{4}$

${ }^{1}$ Fundação Instituto

Mineiro de Estudos e

Pesquisas em Nefrologia - IMEPEN.

${ }^{2}$ Prefeitura Municipal de Juiz de Fora.

${ }^{3}$ Hospital Universitário da Universidade Federal de Juiz de Fora - UFJF.

${ }^{4}$ Departamento de Clínica Médica da UFJF; IMEPEN.

Submitted on: 09/08/2011 Approved on: 09/29/2011

Correspondence to: Natália Fernandes Rua Jamil Altaff, 132 Vale do Ipê Juiz de Fora - MG - Brazil

Zip code 36035-380

E-mail: nataliafernandes02@ gmail.com

This study was undertaken at UFJF.

The authors report no conflicts of interest.

\section{Resumo}

Descreve-se a evolução clínica de um caso de peritonite por Salmonella sp. após episódio de salmonelose intestinal, e uma breve revisão da literatura também foi realizada.

Palavras-chave: Peritonite. Diálise Peritoneal. Infecções por Salmonella.

\section{Case Report}

A 63-year-old male with chronic kidney disease (CKD) on automated peritoneal dialysis (APD) for three years due to diabetic nephropathy, with no previous history of peritonitis and dry abdomen during the day. The patient presented with diffuse abdominal pain, inflammatory diarrhea, and vomits, which had initiated three days earlier. Physical examination revealed a discrete lower limb edema, absence of fever, and no signs of peritonitis. This patient does not use erythropoietin, he presented frequent hypoglycemic episodes and has more than $1,000 \mathrm{~mL}$ of residual diuresis.

The patient was started on intravenous ciprofloxacin for intestinal infection. The routine blood tests, effluent culture, blood culture, and abdominal ultrasound were all normal. Faecal culture was positive for Salmonella sp. and intestinal salmonellosis was diagnosed. After three days, he presented high fever and worsening of abdominal pain, with clinically evident peritonitis. A new effluent culture was positive for Salmonella sp., and the former antibiotic was changed to intravenous amikacin.

After 14 days the starting use of Amikacin, the patient was discharged, but a week later the effluent became once again purulent. He was readmitted to change the Tenckoff catheter and started

\section{Abstract}

We describe the clinical course of a case of peritonitis caused by Salmonella sp. after an episode of intestinal salmonellosis, and a brief review of the literature is also done.

Keywords: Peritonitis. Peritoneal Dialysis. Salmonella Infections.

a new course of four-week intravenous amikacin, leading to heal. A summary of the laboratorial exams are in Table 1.

\section{Discussion AND REVIEW OF LITERATURE}

Salmonella is a gender of Gram-negative Enterobacteriaceae that does not belong to the normal flora of the intestine. Its isolation in feces could mean either unapparent infection, disease, or carrier state. Nearly all cases are caused by food poisoning. ${ }^{1}$ The serotypes $S$. typhi and S. paratyphi are clinically relevant, capable of causing typhoid fever and paratyphoid fever, respectively; S. typhimurium can cause only gastroenteritis, and S. enteritidis, $S$. dublin and $S$. choleraesuis can also lead to bacteremia. ${ }^{2}$

In our environment, Salmonella is rather frequent. Up to $43.1 \%$ of the cases of bacterial diarrhea in São Paulo, between 1999 and 2003, were caused by this agent. ${ }^{3}$ In the Southeast Brazil, the most common serotype is $S$. enteritidis $(67.4 \%)$, followed by $S$. typhimurium. ${ }^{4}$

Spontaneous Salmonella peritonitis can occur in cirrhotic patients with ascites. Other described sites of infection include the pericardium, thyroid, meninges, and bone marrow, mainly due to a deficiency in cellular immunity. In fact, Salmonella persistent bacteremia is a defining criterion of AIDS. ${ }^{5}$ 


\begin{tabular}{lcccc} 
TABLE 1 LABORATORIAL DATE & $\begin{array}{c}\text { First day in the } \\
\text { hospital }\end{array}$ & 3 days after & $\begin{array}{c}\text { Day of the } \\
\text { readmission }\end{array}$ \\
Date & 3,8 & 4,5 & 4.8 & 4.2 \\
\hline Creatinine $(\mathrm{mg} / \mathrm{dL})$ & 78 & 112 & 124 & 98 \\
Urea $(\mathrm{mg} / \mathrm{dL})$ & 12.5 & 11.8 & 11 & 10.2 \\
Hemoglobin (g/L) & 36.2 & 37 & 32 & 33 \\
Hematocrit (\%) & 4200 & 5100 & 4100 & 5100 \\
Leukocytes & 78 & 62 & 128 & 162 \\
Glucose $(\mathrm{mg} / \mathrm{dL})$ & -- & $42 /-$ & $1200 / 80$ & $820 / 88$ \\
Cytometry/neutrophil (\%) & & & \\
\hline
\end{tabular}

Among peritoneal dialysis patients, Salmonella peritonitis is extremely rare, nearly $0.15 \%$ of all the causes. ${ }^{6}$ The serotypes described as agents were to date $S$. enteritidis, S. typhimurium, and S. hadar. Besides manual contamination of the catheter, two mechanisms of translocation could be implicated as the source of peritonitis: either by direct shift to the blood within CD18+ phagocytes, or via invasion of intestinal M cells, later progressing to the lymphoid tissue and regional lymph nodes. ${ }^{7}$

After reviewing the literature, we found three other reported cases of Salmonella peritonitis in peritoneal dialysis patients, but none on APD. Commonly, they all had watery diarrhea, high fever, some degree of immunosuppression, due to a systemic disease or to CKD itself, and presented recurrence of the infection after the initial treatment, because of the difficulty in eliminating the pathogen from the host. ${ }^{8}$

Hence, we conclude that the initial treatment should include at least a quinolone or a third generation cephalosporin or amikacin, and it should last more than four weeks. Then, it should follow peritoneal effluent cultures as fitted. ${ }^{9,10}$ Withdrawal of the Tenckoff catheter is not routinely necessary for the treatment of uncomplicated bacterial peritonitis. ${ }^{10-12}$ Due to the small number of described cases, there is no consensus regarding Tenckoff catheter exchange in cases of recurrent Salmonella peritonitis in peritoneal dialysis. However, we believe that this procedure is to be executed in this particular circumstance. As the need for serial faecal cultures for assessing the condition of carrier, there are few cases in the literature and they are only recommended for patients using immunosuppressive drugs. ${ }^{13}$

\section{References}

1. Mead PS, Slutsker L, Dietz V, et al. Food-related illnesses and death in the United States. Emerg Infect Dis 1999;5:607-25.

2. Brenner FW, Villar RG, Angulo FJ, Tauxe R, Swaminathan B. Salmonella nomenclature. J Clin Microbiol 2000;38:2465-7.
3. Eduardo MBP, Katsuya EM, Bassit NP, Mello MLR. Salmonella enteritidis - uma importante causa de surtos bacterianos veiculados por alimentos e a necessidade de uma nova regulamentação sanitária para os alimentos implicados, São Paulo, Brasil, 1999-2003. Boletim epidemiológico Paulista Agosto, 2004, ano 1, número 8. [cited 2009 Jul 5]. Available from: http://www.cve. saude.sp.gov.br/agencia/bepa8_salmo9903.htm.

4. Fernandes SA, Tavechio AT, Ghilardi AC, Dias AM. Almeida IA, Melo LC. Salmonella serovars isolated from humans in São Paulo State, Brazil, 1996-2003. Rev Inst Med Trop Sao Paulo 2006;48:179-84.

5. Rodriguez M, Diego I, Mendoza C. Extraintestinal salmonellosis in a general hospital (1991 to 1996): relationships between Salmonella genomic groups and clinical presentations. J Clin Microbiol 1998;36:3291-6.

6. Wong SSY, Ho PL, Yuen KY. Evolution of antibiotic resistance mechanisms and their relevance to dialysisrelated infections. Perit Dial Int 2007;27(Suppl):S272-80.

7. Pullinger GD, Paulin SM, Charleston B, et al. Systemic translocation of Salmonella enterica serovar Dublin in cattle occurs predominantly via efferent lymphatics in a cell-free niche and requires type III secretion system 1 (T3SS-1) but not T3SS-2. Infect Immun 2007;75:5191-9.

8. Chiu YL, Huang JW, Hsueh PR, Wu KD, Chu TS. CAPD-related peritonitis due to Salmonella enteritidis in a patient with SLE. Am J Kidney Dis 2005;46:e21-3.

9. Mølbak K, Baggesen DL, Aarestrup FM, et al. An outbreak of multidrug-resistant, quinolone-resistant Salmonella enterica serotype Typhimurium DT104. N Engl J Med 1999;341:1420-5.

10. Swanson SJ, Snider C, Braden CR, et al. Multidrug resistant salmonella enterica serotype Typhimurium associated with pet rodents. $\mathrm{N}$ Engl J Med 2007;356:21-8.

11. Locatelli A, Quiroga MA, De Benedetti L, Gomez M, Barone R, Barron MC. Treatment of recurrent and resistant CAPD peritonitis by temporary withdrawal of peritoneal dialysis without removal of the catheter. Adv Perit Dial 1995;11:176-8.

12. Hakanen A, Kotilanien P, Jalava J, Siitonen A, Huovinen P. Detection of decreased fluoroquinolone susceptibility in Sal.onella and validation of nalidixic acid screening test. J Clin Microbiol 1999;37:3572-7.

13. Medina F, Fraga A, Lavelle C. Salmonella septiv arthritis in systemic lupus erythematosus. The importance of chronic carrier state. J Rheumatol 1989;16:203-8. 